\title{
Tunnekausatiivilauseen argumenttirakenne II
}

\author{
Lausemainen aiheuttaja
}

\author{
SAARA HuhMARNiEmi
}

\section{Johdanto}

Suomen tunnekausatiivilause muodostuu tunnetta ilmaisevasta verbistä, johon liittyy tyypillisesti partitiivimuotoinen kokija (esim. 1a) tai nominatiivimuotoinen aiheuttaja ${ }^{1}$ (esim. 1b) tai kumpikin (1c). Tunnekausatiivilauseen aiheuttaja voi olla myös lausemainen, kuten A-infinitiivi (esim. 2a-b), kun-lause (esim. 3a-b) tai että-lause (esim. $4 \mathrm{a}-\mathrm{b}){ }^{2}$ Lisäksi rakenteeseen voidaan liittää alisteinen kysymyslause (5).

(1) (VISK $\$ 316,905)$

a. Minua nolottaa.

b. Eräs asia harmittaa.

c. Minua alkaa hiljalleen ottaa päähän tämä paikallaan istuminen.

(2) (VISK \$ 503)

a. Margaretaa pelotti mennä ulos, vaikka hänellä oli santarmi seuranaan.

b. Kansalaisia varmasti kiinnostaisi nähdä Lipponen ja Aho vastakkain.

(3) (Suomi24)

a. Ihmetyttää kun pääsiäisenä myytiin valmiiksi keitettyjä ja värjättyjä kananmunia.

b. Hävettää, kun ees kirjoitin näin ääliömäiseen ketjuun.

1. Iso suomen kielioppi käyttää aiheuttajasta termiä ärsyke (VISK \ 465).

2. A-infinitiiviä ei yleensä pidetä lauseena vaan verbilausekkeena. Tämä artikkeli ei ota kantaa Ainfinitiivin rakenteeseen tarkemmin; termiä lausemainen käytetään kokoamaan yhteen kolme argumenttityyppiä ja erottamaan ne NP:istä. 
(4) (Suomi24)

a. Tympii että selän takana puhutaan ja sitten ite saa oikoa niitä asioita - -

b. Huvittaa että jeesustelette tatuoinneista.

(5) Tilinpäätöstä analysoidessa minua kiinnostaa, onko yhtiö pystynyt suoriutumaan verovelvoitteistaan, - - (Internet 1$)$

Tämä artikkeli on toinen osa kahden artikkelin sarjasta. Ensimmäisessä osassa (ks. Huhmarniemi 2019) käsittelin sellaisen tunnekausatiivilauseen argumenttirakennetta, jossa aiheuttaja ja kokija ovat molemmat substantiivilausekkeita (NP). ${ }^{3}$ Artikkelissa esitin, että suomen tunnekausatiivilause muodostetaan tyypillisesti rakenteesta, jossa aiheuttaja on ylempänä kuin kokija ja sanajärjestyksen variaatio on seurausta rakenteessa tapahtuvista siirtymistä. Tämä artikkeli täydentää tutkimusta lausemaisten aiheuttajien analyysillä. Ensimmäisen osan tavoin hyödynnän tunnekausatiivilauseen syntaktisessa analyysissä generatiivisen tutkimusparadigman välineistöä (ks. mas. 378-382). Tavoitteeni on osoittaa, että toisin kuin NP lausemainen aiheuttaja asettuu argumenttirakenteessa kokijan alapuolelle. Tästä seuraa, että tunnekausatiivilauseen argumenttirakenne vaihtelee aiheuttaja-argumentin tyypin mukaan.

A-infinitiivi, että-lause ja alisteinen kysymyslause ovat tunnekausatiivilauseen täydennyksiä. Sen sijaan kun-lause voi toimia joko täydennyksenä tai temporaalisena tai kausaalisena määritteenä. Tässä artikkelissa osoitan, että A-infinitiivi ja että-lause sijoittuvat tunnekausatiivilauseen rakenteessa komplementtipositioon. Lisäksi näytän kieliopillisten testien avulla, että aiheuttajana toimiva kun-lause voi sijoittua joko adjunktipositioon tai komplementtipositioon. Alisteisia kysymyslauseita en tässä artikkelissa käsittele tarkemmin. Kutsun täydennyksiä tästä eteenpäin argumenteiksi.

Täydennän tunnekausatiivilauseen kieliopillista analyysiä korpusaineiston tarkastelulla. Aineistoksi olen valinnut Suomi24-korpuksen, jossa tunnekausatiivit ovat hyvin edustettuina. Analyysissä kiinnitän huomiota siihen, millaisten tunnekausatiiviverbien yhteydessä lausemainen aiheuttaja esiintyy, ja jaottelen verbit mentaalisiin tunneverbeihin (kuten hävettää) ja ruumillista tuntemusta ilmaiseviin tuntemusverbeihin (kuten yskittää) (verbien luokista ks. VISK \$ 465, 467).

Artikkeli rakentuu seuraavasti: Esittelen tunnekausatiivilauseen perusrakenteen lyhyesti luvussa 2. Luvussa 3 tarkastelen A-infinitiivin asemaa tunnekausatiivilauseessa anaforien sidontaan ja komplementtien tunnistamiseen liittyvien kieliopillisten testien avulla. Luvussa 4 käsittelen että-lausetta ja luvussa 5 kun-lausetta. Luvussa 6 tarkastelen sitä, miten lausemaiset aiheuttajat esiintyvät korpusaineistossa erilaisten tunnekausatiiviverbien yhteydessä. Luku 7 kokoaa keskeiset päätelmät. ${ }^{4}$

3. Tarkasteluun on otettu ainoastaan NP:t, jotka eivät sisällä lausemaista osaa. Esimerkiksi lauseessa Minua harmittaa [se, että en löydä sinua] aiheuttaja on NP, joka sisältää lausemaisen osan. Nämä lauseet jäävät artikkelisarjan ensimmäisessä osassa analyysin ulkopuolelle.

4. Olen kiitollinen Anne Vainikalle arvokkaista kommenteista käsikirjoituksen aiempaan versioon. Kiitokset myös Kielitieteen päivien 2018 yleisölle sekä nimettömille arvioijille kommenteista. Tätä tutkimusta on rahoittanut Koneen Säätiö. 


\section{Tunnekausatiivilauseiden tulkinta ja rakenne}

Artikkelisarjan ensimmäisessä osassa esitin tunnekausatiivilauseelle kuvion 1 mukaisen argumenttirakenteen (ks. Huhmarniemi 2019: 385). Rakenne sisältää pääsanan Caus, joka tuo lauseeseen kausatiivimorfeemin. On huomattava, että tunnekausatiivit eivät aina ilmaise tilan muutosta tai sen aiheuttamista vaan myös pelkkää tilaa tai tunnetilaa (esim. VISK $\$ 467$; Hakulinen \& Karlsson 1979: 244; Pörn 20o1; Pylkkänen 2002; Cathcart \& Vainikka 2019). Pääsana ei siis välttämättä tuo rakenteeseen kausatiivista merkityssisältöä, vaan merkitys muodostuu yhdessä lauseen muiden tekijöiden kanssa. ${ }^{5}$ Tunnekausatiivilauseen argumenttirakennetta ovat aiemmin tutkineet muiden muassa Siro (1996 [1978]), Siiroinen (2001, 2005), Nelson (2000, 2003), Pylkkänen (2002) ja Kupula (2010).

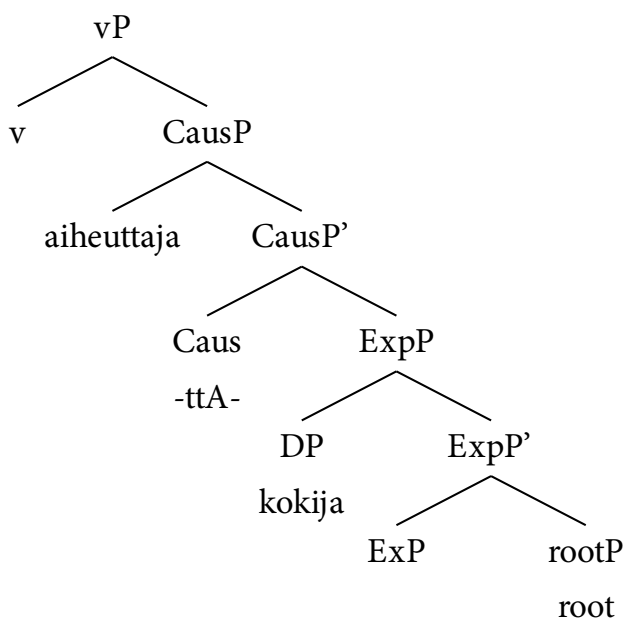

Kuvio 1.

Tunnekausatiivilauseen argumenttirakenne.

Kuvion 1 rakennetta ei kuitenkaan voida suoraan soveltaa tunnekausatiivilauseisiin, joilla on lausemainen aiheuttaja-argumentti. Luvuissa 3-5 tarkastelen lausemaisten aiheuttajien sijaintia rakenteessa. Aloitan tarkastelun A-infinitiivistä.

\section{A-infinitiivin asema tunnekausatiivilauseen argumenttirakenteessa}

Tunnekausatiivilause voi ottaa aiheuttaja-argumentikseen A-infinitiivin, kuten voidaan havaita esimerkeistä 6a-b (ks. myös Leino 1986). Transitiivilauseessa A-infinitiivi asettuu verbin komplementtiin (Vainikka 1989: 272-286; Toivonen 1995; Koskinen 1998:

5. Kuviossa 1 esitetyn rakenteen lisäksi finiittiset ja useimmat infiniittiset lauseet sisältävät T(ense) pääsanan vP:n päällä. TP sisältää aikamuodon ja yleensä myös verbin taivutuspiirteet. Lauseen teemapaikka sijaitsee TP-lausekkeen määritteessä. 
230-294). Tässä luvussa osoitan, että A-infinitiivi asettuu komplementtipositioon myös tunnekausatiivilauseessa. ${ }^{6}$

(6) (VISK $\$ 503)$

a. Margaretaa pelotti mennä ulos, vaikka hänellä oli santarmi seuranaan.

b. Kansalaisia varmasti kiinnostaisi nähdä Lipponen ja Aho vastakkain.

Argumenttien sijainnista lauserakenteessa on mahdollista saada vihjeitä erilaisten kieliopillisten testien avulla. Suomessa esimerkiksi anaforien sidonta määrittyy argumenttirakenteen perusteella. Käsittelen anaforien sidontaan liittyviä testejä alaluvussa 3.1; alaluvussa 3.2 esittelen puolestaan erilaisia testejä, jotka tukevat A-infinitiivin sijoittamista komplementtipositioon. Alaluvussa 3.3 esitän ehdotuksen A-infinitiivin asemasta tunnekausatiivilauseessa.

\subsection{Anaforien sidonta}

Anaforien sidontaa koskevat testit tukevat analyysiä, jossa tunnekausatiivilauseen kokija on argumenttirakenteessa ylempänä kuin A-infinitiivi. Tässä luvussa tarkastelen kahta sidontaehtoa, refleksiivisiin anaforiin liittyvää sidontaehtoa A (condition $A$ ) ja pronomineihin liittyvää sidontaehtoa B (condition B) (Chomsky 1981).

Sidontaehdon A mukaan refleksiivinen anafora vaatii paikallisen k-komentavan korrelaatin. Solmu X k-komentaa solmua Y (c-command, constituent-command), mikäli Y on X:n sisar tai X:n sisaren jälkeläinen. ${ }^{7}$ Refleksiivisellä anaforalla tarkoitetaan refleksiivipronominia, resiprookkipronominia ja refleksiivistä possessiivisuffiksia -nsA (Vainikka 1989; Trosterud 1993; VISK \$ 1445). Paikallisuudella tarkoitetaan tässä yhteydessä sitä, että sidonta ei voi ylittää finiittilauseen rajaa (ks. tarkemmin Huhmarniemi 2019: 379-381).

Esimerkkien $7 \mathrm{a}-\mathrm{b}$ perusteella kokija Pekkaa voi toimia A-infinitiivin objektiargumentin korrelaattina. Tämä on sidontaehdon A perusteella mahdollista ainoastaan, jos kokija k-komentaa anaforaa ja on näin ollen rakenteessa ylempänä kuin A-infinitiivi.

(7) a. Pekkaa harmitti [katsella itseään]. ${ }^{8}$

b. Pekkaa harmitti [katsella autoaan].

6. Iso suomen kielioppi käyttää komplementeista termiä täydennys (VISK \$ 439). Täydennys tarkoittaa kuitenkin enemmän sanan tai rakenteen valenssiin liittyvää laajennusta, joka voi kohdistua syntaktisessa rakenteessa erilaisiin positioihin. Tässä artikkelissa olen kiinnostunut nimenomaan syntaktisesta komplementtipositiosta.

7. Määritelmän mukaan siis esimerkissä (i) solmu B k-komentaa solmuja C, D, E, F ja G. Toisaalta esimerkiksi solmu $\mathrm{H}$ k-komentaa solmua I, mutta ei muita rakenteen solmuja.

(i)

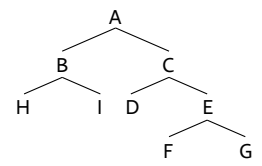

8. Esimerkit, joissa ei ole lähdeviitemerkintää, ovat itse keksimiäni. 
Tarkastelen seuraavaksi toista anaforiin liittyvää testiä. Anaforien sidontaehdon B mukaan pronominin tulee olla vapaa paikallisessa kontekstissa (Chomsky 1981). Esimerkiksi transitiivilauseen subjekti ja objektipositiossa oleva pronomini eivät voi olla samaviitteisiä (esim. 8a). Sama pätee tunnekausatiivilauseessa kokijan ja A-infinitiivin objektiargumentin välillä (esim. 8b). Esimerkki $8 \mathrm{c}$ osoittaa vertailun vuoksi, että pronominin korrelaatti voi esiintyä samassa lauseessa, mikäli se ei k-komenna pronominia. Esimerkin 8b perusteella kokija siis k-komentaa A-infinitiivin objektiargumenttia ja on näin ollen ylempänä rakenteessa kuin A-infinitiivi.

(8) a. Pekka pitää hänestä. *hän=Pekka

b. Pekkaa harmitti katsella häntä. ${ }^{\star}$ hän=Pekka

c. Minua harmitti [Pekan puolesta] katsella häntä.

Anaforien sidontaehtojen A ja B avulla voidaan siis päätellä elementtien suhteellisia sijainteja argumenttirakenteessa. Ehdoista ei voi kuitenkaan päätellä, onko A-infinitiivi komplementti vai rakenteessa kokijan alapuolella sijaitseva adjunkti. Komplementti- ja adjunktipositioihin liittyviä testejä käsittelen seuraavassa alaluvussa.

\subsection{Komplementtipositiota määrittävät testit}

Lausekkeen komplementti- ja adjunktipositioiden erottamiseksi on olemassa joukko kieliopillisia testejä (esim. Haegeman 1991), joita hyödynnän tässä soveltuvin osin. A-infinitiivin komplementtipositiota puoltavat seuraavat havainnot:

Testi 1. A-infinitiivi on valikoiva verbien suhteen, kuten esimerkit $9 \mathrm{a}-\mathrm{b}$ osoittavat. Tämä on tyypillinen komplementin ominaisuus. Palaan tähän valikoivuuteen alaluvussa 6.2.

(9) a. ${ }^{\star}$ Minua janottaa lähteä kotiin.

b. Minua väsyttää lähteä kotiin.

Testi 2. A-infinitiivejä voi olla rakenteessa vain yksi, mikä on tavallista komplementille. Testi 3. A-infinitiivi korvaa nominatiivimuotoisen aiheuttaja-argumentin. Samassa lauseessa ei voi esiintyä sekä nominatiivimuotoista aiheuttajaa että A-infinitiiviä (esim. 10a-b). Tällä perusteella A-infinitiivi on lauseen argumentti.

(10) a. Ukkonen pelotti Margaretaa.

b. ${ }^{\star}$ Ukkonen Margaretaa pelotti mennä ulos.

Testi 4. A-infinitiivi sijaitsee välttämättä verbin jäljessä kuten tyypilliset komplementit. Testi 5. A-infinitiivi ei voi siirtyä kokonaisena, kuten esimerkit 11a-b osoittavat.

(11) a. ${ }^{*}\left[\right.$ Mihin mennä] harmittaa sinua? / ${ }^{*}$ [Mihin mennä] sinua harmittaa? b. ${ }^{*}[$ Pestä ikkunat $]$ inhottaa minua. $/{ }^{*}[$ Pestä ikkunat $]$ minua inhottaa. 
Testi 6. Siirtymä A-infinitiivin sisältä on mahdollinen (esim. 12a-b).

(12) a. Mitä sinua inhottaa [tehdä__]?

b. Mihin sinua harmittaa [mennä__]?

Testit 5-6 perustuvat havaintoon, että adjunkti- tai määritepositiossa sijaitsevat lausekkeet ovat tyypillisesti saarekkeita. Ne liikkuvat kokonaisina eivätkä salli elementtien siirtyvän ulos lausekkeesta (Ross 1967; Huhmarniemi 2012). A-infinitiivi ei ole saareke eikä siirry kokonaisena, mikä viittaa siihen, että se on adjunktin sijasta komplementti.

Testi 7. A-infinitiivi käyttäytyy finiittiverbin ellipsissä komplementin tavoin. Finiittiverbin ellipsin avulla voidaan tunnistaa verbin komplementtipositiossa sijaitsevia elementtejä. Tämä havaitaan, kun tarkastellaan rinnastuskonjunktiolla yhdistettyjä lauseita. Esimerkeissä 13a-b rinnastuskonjunktion toisen jäsenen finiittiverbi on jätetty lausumatta ja rakenne sisältää kin-partikkelin. Finiittiverbin ellipsin jäljelle jäävä jakso sisältää tyypillisesti subjektin, mutta siinä voi esiintyä myös adverbiaaleja, objekteja ja genetiivimääritteitä (VISK $\$ 1189$ ).

(13) a. Minä ostin kirjan ja niin Pekkakin.

b. Minä ostin kirjan tänään ja niin Pekkakin eilen.

Esimerkin 14a rakenteessa verbin jälkeen esiintyvä objekti ei voi esiintyä finiittiverbin ellipsin jäljelle jäävässä osassa. Sama pätee A-infinitiiviin (esim. 14b).

(14) a. ${ }^{\star}$ Minä ostin kirjan (eilen) ja niin Pekkakin television.

b. ${ }^{\star}$ Minä halusin mennä ulos (eilen) ja niin Pekkakin tehdä töitä.

Vastaavasti tunnekausatiivilauseessa verbinjälkeinen aiheuttaja ei säily elliptisessä rakenteessa (esim. 15a-b), mutta adverbiaalit, jotka liittyvät rakenteeseen adjunktina, sen sijaan säilyvät (esim. 15c).

(15) a. Pekkaa huvitti tämä ohjelma ja niin Merjaakin.

b. ${ }^{\star P e k k a a ~ h u v i t t i ~ t a ̈ m a ̈ ~ o h j e l m a ~ j a ~ n i i n ~ M e r j a a k i n ~ t u o ~ o h j e l m a . ~}$

c. Pekkaa huvitti tämä ohjelma eilen ja niin Merjaakin tänään.

A-infinitiiviä ei ole mahdollista käyttää vastaavassa elliptisessä rakenteessa (esim. 16). Tämä testi tukee hypoteesia, että A-infinitiivi ei ole adjunkti.

(16) *Pekkaa harmitti mennä ulos ja niin Merjaakin tehdä töitä.

Yhteenvetona voidaan todeta, että A-infinitiivillä on tunnekausatiivilauseessa useita argumentin ja komplementin ominaisuuksia mutta ei lainkaan tyypillisten adjunktien ominaisuuksia. 


\subsection{A-infinitiivin asema tunnekausatiivilauseessa}

Kun A-infinitiivi esiintyy tunnekausatiivilauseessa, se ei sisällä ilmi pantua subjektia, vaan subjektiksi tulkitaan hallitsevan tunnekausatiiviverbin kokijaobjekti (VISK $₫$ 503). Oletan, että infiniittinen rakenne sisältää tyhjän PRO-subjektin (esim. 17a-b), joka saa verbiltä temaattisen roolin (Koskinen 1998: 261). PRO-elementti on generatiivisen kielioppiperinteen keino esittää sellainen argumentti, jolla on syntaktinen tehtävä mutta jota ei ole ilmipantu. Toisin kuin päälauseen tyhjällä subjektilla (esim. lauseessa Lähdin kotiin), PRO-elementillä on aina oltava k-komentava korrelaatti (Chomsky 1981).

(17) a. Minua ${ }_{i}$ harmittaa $\left[\mathrm{PRO}_{\mathrm{i}}\right.$ mennä kouluun $]$.

b. Pekkaa inhottaa $\left[\mathrm{PRO}_{i}\right.$ pestä ikkunat $]$.

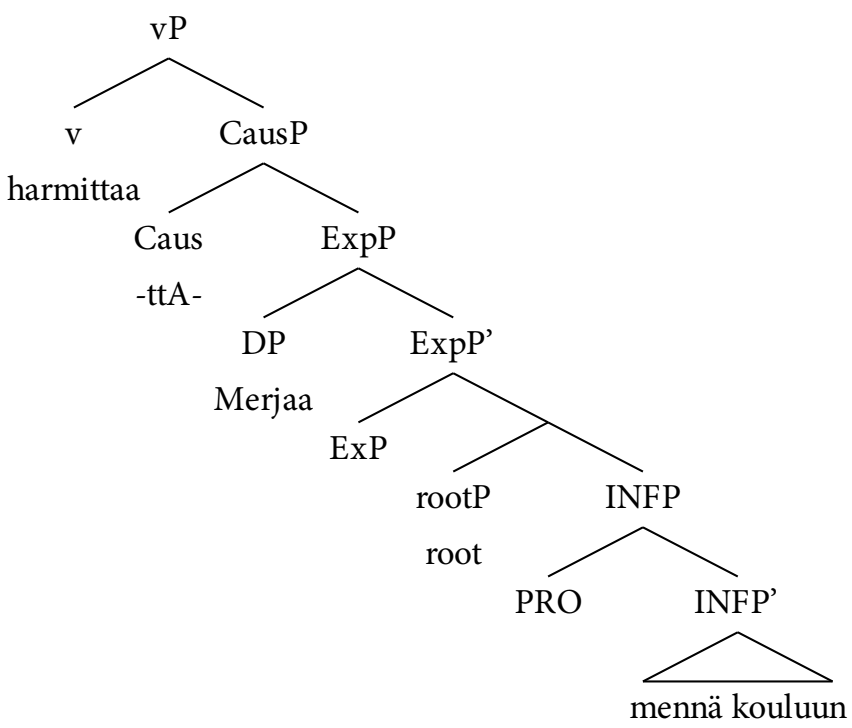

Kuvio 2.

A-infinitiivin sijainti tunnekausatiiviverbin komplementissa.

A-infinitiivin sisältävän tunnekausatiivilauseen rakenne on esitetty kuviossa 2. Esitetty rakenne poikkeaa artikkelisarjan ensimmäisessä osassa esittelemästäni rakenteesta (ks. kuviota 1 s. 500). Substantiivimuotoista aiheuttajaa koskevat kieliopilliset testit tukevat analyysiä, jonka perusteella aiheuttaja asettuu CausP-lausekkeen määritteeseen, kokijan yläpuolelle. Kuvion 2 rakenteessa Caus-pääsanan määrite sen sijaan jää tyhjäksi. Syntaktisen analyysin kannalta voidaan nähdä ongelmana, että saman temaattisen roolin saavat elementit (NP ja A-infinitiivi) sijoittuvat rakenteessa eri positioihin ja yksi argumenttipositio jää käyttämättä. Tätä ongelmaa voi lähestyä ainakin kolmesta näkökulmista.

Yksi vaihtoehto on se, että aiheuttajana NP:llä ja A-infinitiivillä on toisistaan eroava temaattinen rooli ja ne sijoittuvat tämän takia rakenteessa eri positioihin. Tietääkseni tällaista vaihtoehtoa ei ole aiemmin esitetty. Temaattisten roolien selvittäminen vaatisi tarkemman semanttisen analyysin erityyppisille aiheuttaja-argumenteille. 
Toisen vaihtoehdon mukaan molemmat lausekkeet sijoitetaan ensin komplementtipositioon, josta aiheuttaja-NP siirtyy CausP-lausekkeen määritteeseen. ${ }^{9}$ Tästä vaihtoehdosta seuraa kuitenkin ongelmia muun muassa anaforien sidontasuhteiden kannalta; näitä suhteita käsittelin artikkelisarjan ensimmäisessä osassa (Huhmarniemi 2019: 386-389). Koska sidontasuhteet määritellään argumenttirakenteen perusteella ennen siirtymiä, esimerkki 18a olisi kieliopillinen mutta esimerkki 18b ei. Näin ei kuitenkaan ole, vaan esimerkki 18b on mahdollinen suomen kielen lause.

(18) a. ?Pekkaa harmittaa itsensä.

b. Pekka harmittaa itseään.

Artikkelisarjan ensimmäisessä osassa oletin, että esimerkki 18a on erityistapaus, joka on muun muassa sidottu tiettyyn sanajärjestykseen (Huhmarniemi 2019: 388). Esimerkiksi lause 19a, jossa aiheuttaja olisi siirtynyt komplementista ylempään positioon, on epäkieliopillinen, vaikka siirtymä teemapaikkaan ei suomessa yleensä muuta sidontasuhteita (esim. 19b-c).

(19) a. ${ }^{\star}$ Itsensä harmittaa Pekkaa.

b. Pekka rakastaa itseään.

c. Itseään rakastaa Pekka.

Kolmas vaihtoehto on, että tunnekausatiiveilla on kaksi positiota aiheuttajaargumentille, toinen CausP-lausekkeen määritteessä ja toinen komplementissa, ja niissä molemmissa voidaan kiinnittää aiheuttajan temaattinen rooli. Lausemaisille aiheuttajille komplementtipositio on ainoa mahdollinen, kun taas NP:t sijoittuisivat tyypillisesti CausP-lausekkeen määritteeseen mutta voisivat erityistapauksissa sijoittua myös komplementtiin. Tämä vaihtoehto selittää osan etenkin anaforien sidontaan liittyvästä vaihtelusta esimerkiksi lauseissa 18a ja 20.

(20) ?Pekkaa surettavat oppilaansa.

Seuraavaksi tarkastelen lyhyesti että-lauseen sijaintia tunnekausatiivilauseessa.

\section{Että-lauseen asema tunnekausatiivilauseessa}

Suomi24-korpuksessa että-lause esiintyy yleisesti tunnekausatiivilauseen aiheuttajana hyvin monenlaisten verbien yhteydessä (esim. 21a-e).

9. On myös mahdollista tulkita, että A-infinitiivi saa aiheuttaja-tulkinnan siirtymällä CausP-lausekkeen määritteeseen. A-infinitiivi ei kuitenkaan yleensä siirry, vrt. *?[Pestä astioita] on Pekan lempipuuhaa (Huhmarniemi 2012). Toisaalta jos A-infinitiivin siirtymä ylempiin positioihin olisi yleisesti mahdollista, tulisi myös sellaisten rakenteiden kuin *Pestä astioita harmittaa minua olla kieliopillisia. 


\section{(21) (Suomi24)}

a. - - mut hieman kuumottaa että mikä tässä mättää - -

b. Minua kuvottaa että se on elävästä olennosta peräisin ja eläin on joutunut kärsimään.

c. Tympii että selän takana puhutaan ja sitten ite saa oikoa niitä asioita - -

d. Huvittaa että jeesustelette tatuoinneista.

e. Todella sapettaa että kukaan ei usko kun väität itseäsi voittajaksi.

Alaluvun 3.2 komplementtitestit 1-5 pätevät myös että-lauseeseen: että-lause on valikoiva verbien suhteen (ks. lukua 6), että-lauseita voi olla vain yksi, että-lause korvaa aiheuttaja-NP:n, se sijaitsee verbin jäljessä eikä yleensä liiku kokonaisena. Sen sijaan elementtien siirtämistä ulos että-lauseesta ei voida käyttää luotettavana testinä, sillä siirtymät että-lauseista ovat melko rajoitettuja myös muissa konteksteissa (Huhmarniemi 2012). Komplementtiasemaa tukee lisäksi havainto, että lause ei voi esiintyä finiittiverbin ellipsissä yhtä aikaa kokijan kanssa (esim. 22a). Esimerkki 22b osoittaa, että sen sijaan adverbiaali voi esiintyä ellipsissä.

(22) a. *Pekkaa harmitti että sataa ja niin Merjaakin että on kylmä.

b. Pekkaa harmitti eilen että sataa ja niin Merjaakin toissapäivänä.

On siis perusteltua olettaa, että myös että-lause sijaitsee tunnekausatiivilauseen argumenttirakenteessa komplementtipositiossa. ${ }^{10}$

\section{Kun-lauseen asema tunnekausatiivilauseessa}

Kun-lause voi toimia tunnekausatiivilauseessa aiheuttajana (esim. 23a-c) tai temporaalisena tai kausaalisena määritteenä $(24 a-c)$.

(23) (Suomi24)

a. Ihmetyttää kun pääsiäisenä myytiin valmiiksi keitettyjä ja värjättyjä kananmunia.

b. Vituttaako kun argumentit loppui?

c. Hävettää, kun ees kirjoitin näin ääliömäiseen ketjuun.

(24) (Suomi24)

a. Minulla alkaa nenä vuotaa ja aivastuttaa, kun luen tuoretta sanomalehteä.

b. Minua oikein huimasi, kun sain tämän oivalluksen.

c. Tämä kielioppi vaan ihmetyttää, kun minun aapisessa ei henkilöistä puhuta ketä sanalla.

\footnotetext{
10. Oman luokkansa muodostavat rakenteet, jotka sisältävät NP:n, johon että-lause liittyy, kuten Se eniten sapettaa, että--. Että-lause sijaitsee usein erillään pääsanasta myös muissa kuin tunnekausatiivilauseissa. Nämä rakenteet jäävät tarkastelun ulkopuolelle. 
Pörn (2001) esittää, että kun-lause voi toimia tunnekausatiivilauseessa aiheuttajaargumenttina, mutta lause liittyy silti syntaktiseen rakenteeseen adjunktoitumalla. Asetun tässä eri kannalle ja väitän, että kun-lause voi asettua myös komplementtipositioon.

Tarkastelen ensin kun-lausetta adjunktina. Esimerkki 25a sisältää sekä aiheuttajana toimivan kun-lauseen että A-infinitiivin ja esimerkki 25b aiheuttaja-NP:n (ks. myös esim. 24c). Koska argumenttipositiot ovat täynnä, kun-lauseen täytyy asettua rakenteessa adjunktipositioon.

(25) a. Kauppareissun jälkeen melkeen harmitti mennä ulos kun oli alkanut sataa, mutta - - (Internet 2)

b. Poisto harmitti minua, kun kirjoitukseni oli saanut monia oikein hyviä vastineita. (Suomi24)

Kuten tyypilliset adjunktit, kun-lauseet voivat esiintyä erilaisten verbien kanssa, ne voivat liikkua rakenteessa kuten adjunktit, niitä voi olla rakenteessa useampia ja ne eivät välttämättä korvaa aiheuttaja-argumenttia. Finiittiverbin ellipsissä rakenne käyttäytyy kuin adjunkti (esim. 26).

(26) Minua huimasi kiivetä vuorelle ja niin Pekkaakin, kun hän katsoi alas.

Näyttää siis siltä, että kun-lause voi saada aiheuttajatulkinnan myös adjunktipositiossa, verbin syntaktisen argumenttirakenteen ulkopuolella. Adjunktipositiossa kun-lause määrittää koko tunnekausatiivilauseen ilmaisemaa tapahtumaa.

Tarkastelen seuraavaksi testejä, jotka tukevat $k u n$-lauseen sijoittamista komplementtipositioon. Useimpia komplementtitesteistä ei ole mahdollista hyödyntää rakenteen monitulkintaisuuden takia, mutta tietyissä rakenteissa $k u n$-lause ei liiku yhtä vapaasti kuin toisissa. Esimerkissä 27a kun-lause ei voi saada temporaalista tulkintaa; se ei myöskään liiku (esim. 27b). Vertailun vuoksi todettakoon, että adjunktina toimivat kunlauseet voivat liikkua (esim. 27c).

(27) a. Hävettää, kun ees kirjoitin näin ääliömäiseen ketjuun.

b. ${ }^{\star}$ [Kun ees kirjoitin näin ääliömäiseen ketjuun], (mua) hävettää.

c. Kun sain tämän oivalluksen, minua huimasi.

Toinen tapa testata kun-lauseen syntaktista positiota on sen rinnastaminen samanarvoisen konstituentin kanssa. Rinnastuskonjunktiot liittävät toisiinsa kieliopillisesti samanarvoisia elementtejä, kuten komplementteja tai adjunkteja. A-infinitiivin voi rinnastaa kun-lauseen kanssa (esim. 28). Tämä havainto tukee analyysiä, jonka mukaan myös kun-lause voi A-infinitiivin tapaan esiintyä komplementtipositiossa.

(28) Minua harmittaa tehdä virheitä ja kun suutuin ystävälleni. 
Edellä esittämäni perusteella katson, että adjunktiposition lisäksi kun-lause voi esiintyä tunnekausatiivilauseen argumenttirakenteessa komplementtina ja ottaa näin ollen myös aiheuttaja-argumentin temaattisen roolin. Herlinin (1998: 75) mukaan kun-lause voi saada tunnekausatiivien yhteydessä subjektimaisia piirteitä. Keskeistä on näkökulma; subjektiksi analysoituva kun-lause ilmaisee subjektiivista näkökulmaa päälauseen ilmaisemaan tilanteeseen. Herlin ei käsittele asiaa tarkemmin, mutta mahdolliset kun-lauseen subjektimaiset ominaisuudet voivat olla yhteydessä kun-lauseen argumenttiasemaan.

\section{Tunnekausatiivien luokittelu korpusaineiston valossa}

Iso suomen kielioppi luokittelee tunnekausatiivit mentaalista tilaa tai tilan muutosta kuvaaviin tunneverbeihin, kuten harmittaa, kaduttaa ja inhottaa, ja tyypillisesti ruumiillista tilaa kuvaaviin tuntemusverbeihin, kuten yskittää, aivastuttaa tai oksettaa (VISK $\$ 465,467)$. Toisaalta Pörn (2001) on esittänyt, että tunnekausatiivit voidaan jakaa pakollisesti tai valinnaisesti kausatiivisiin verbeihin. Pakollisesti kausatiiviset verbit vaativat aina aiheuttajan, joka voi olla myös implisiittinen, kun taas valinnaisesti kausatiiviset verbit eivät välttämättä edellytä aiheuttajaa. Tässä luvussa tarkastelen molempia luokituksia Internet-keskusteluaineiston valossa. Tarkastelu osoittaa, että verbin luokka korreloi lausemaisen aiheuttajan yleisyyden kanssa, mutta verbien luokitus ei ole selvärajainen vaan muodostaa jatkumon. Lisäksi useimmat tarkasteluun otetuista tuntemusverbeistä esiintyvät keskusteluaineistoissa myös konteksteissa, joissa niitä käytetään tunnetilan ilmaisemiseen.

\subsection{Tunnekausatiivien semanttiset luokat}

Lähden liikkeelle verbistä kyllästyttää, joka on Pörnin (2001) esittämän tunnekausatiivien luokittelun mukaan valinnaisesti kausatiivinen. Esimerkistä 29a voidaan ajatella, että juhla aiheuttaa Pekan psyykkisen tilan; esimerkin 29b taas voidaan tulkita kuvaavan itse psyykkistä tilaa tai siinä olemista. Valinnaisesti kausatiivisilla verbeillä aiheuttaja voi siis olla implisiittinen tai puuttua kokonaan.

(29)a. Juhla kyllästyttää Pekkaa.

b. Pekkaa kyllästyttää.

Pörn (2001: 116) antaa valinnaisesti ja pakollisesti kausatiivisista verbeistä seuraavanlaisia esimerkkejä:

Valinnaisesti kausatiivisia tunnekausatiiveja: heikottaa, hihityttää, itkettää, janottaa, kuvottaa, naurattaa, nukuttaa, oksettaa, pyörryttää, väsyttää

Pakollisesti kausatiivisia tunnekausatiiveja: harmittaa, hermostuttaa, inhottaa, kaduttaa, kauhistuttaa, pelottaa, suututtaa, säälittää 
Nämä luokat ovat osittain päällekkäiset Ison suomen kieliopin tunne- ja tuntemusverbien luokittelun kanssa (VISK $\$ 465,467$ ). ${ }^{11}$ Siinä missä tunneverbit ilmaisevat mentaalista tilaa, tuntemusverbit yhdistetään useammin ruumiilliseen tuntemukseen.

Tuntemusverbejä: aivastuttaa, heikottaa, heitättää, hikoiluttaa, hiukoa, huimata, janottaa, jomottaa, kihelmöidä, kirvellä, kutista, kuumottaa, kuvottaa, nikottaa, nukuttaa, närästää, oksettaa, palella, pissattaa, puistattaa, pyörryttää, raukaista, vihloa, viluttaa, yskittää

Tunneverbejä: ahdistaa, harmittaa, hermostuttaa, hirvittää, huvittaa, hävettää, ihmetyttää, inhottaa, jännittää, kaduttaa, kammottaa, kiukuttaa, korveta, miellyttää, nolottaa, pänniä, risoa, sapettaa, surettaa, säälittää, tympiä, ujostuttaa, vituttaa, ällöttää

Pörn (2001) määrittelee kausatiivisuuden tunnistamista varten diagnostisen testin, jonka mukaan pakollisesti kausatiivisiin tunnekausatiiveihin liitetty kun-lause tulkitaan välttämättä aiheuttaja-argumentiksi. Esimerkissä 3oa siis kun-lause olisi välttämättä aiheuttaja, kun taas esimerkissä zob vastaava kun-lause voisi saada joko temporaalisen tai kausaalisen tulkinnan.

(30) a. Minua inhottaa $\sim$ kaduttaa $\sim$ harmittaa, kun olen hermostunut.

b. Minua itkettää janottaa, kun olen hermostunut.

Tämä testi ei ole kuitenkaan ongelmaton. Kun-lause voi tietyissä konteksteissa saada temporaalisen tulkinnan myös pakollisesti kausatiivisten verbien kanssa, kuten Pörn (2001: 126) huomauttaa. Niinpä esimerkeissä 31a-b kun-lause voidaan tulkita temporaaliseksi.

(31) a. Mikä Meitä Pelotti kun Lähdettiin Yrittäjiksi? (Internet 3)

b. Minua ja kahta naispuolista ruotsalaista ystävääni hermostutti, kun matkasimme hissillä ylös kahvilaan. Emme oikein tienneet, mitä odottaa. (Internet 4)

Vaikuttaa siis siltä, että testi ei luotettavasti erottele verbiluokkia. On mahdollista, että Pörnin havaitsema tendenssi, jonka mukaan pakollisesti ja valinnaisesti kausatiiviset tunnekausatiivit voitaisiin erotella toisistaan kun-lauseiden tulkinnan perusteella, on seurausta siitä, että tunneverbit ottavat kun-lauseen useammin aiheuttaja-argumentiksi kuin tuntemusverbit. Tunneverbeillä yleisemmin käytössä oleva komplementtipositio on siis yhteydessä myös tunnekausatiivin tulkintaan.

\subsection{Lausemaiset aiheuttajat tunnekausatiivilauseessa}

Olen analysoinut tunnekausatiivilauseen rakennetta myös korpusaineiston avulla. Aineistona olen käyttänyt Suomi24-korpusta (Lagus, Panzar, Ruckenstein \& Ylisiurua

11. Kiitos nimettömälle arvioijalle tästä huomiosta. 
2016). ${ }^{12}$ Korpuksen koko on yhteensä 2,7 miljardia sanaa. Valitsin korpuksesta 36 tunnekausatiiviverbin indikatiivimuotoiset esiintymät, joita on yhteensä noin 484 ooo. Tarkasteltavina verbeinä ovat 18 tunneverbiä (421 ooo esiintymää) ja 18 tuntemusverbiä (63 ooo esiintymää). ${ }^{13}$ Verbit, jotka esiintyvät myös perussubjektillisissa rakenteissa, olen jättänyt aineiston ulkopuolelle. Tunnekausatiivilauseiden ominaisuuksia etsin CQPhakulausekkeilla (Corpus Query Protocol) Korp-käyttöliittymän avulla. Esittelen seuraavaksi katsauksen A-infinitiivejä, kun-lauseita ja että-lauseita koskevaan aineistoon.

\subsubsection{A-infinitiivi}

A-infinitiivi on korpusaineiston perusteella tunnekausatiivilauseessa aiheuttaja tai ärsyke, eikä sillä näytä olevan muita rooleja. A-infinitiivi esiintyy tunnekausatiiviverbin jäljessä keskimäärin 5 prosentissa kaikista tunnekausatiivin indikatiivimuotoisista esiintymistä. Kuviossa 3 on esitetty A-infinitiivin verbikohtainen jakauma tarkasteluun valittujen verbien osalta. Aineistoa on rajattu niin, että mukana ovat vain tapaukset, joissa lauseke seuraa välittömästi verbiä, kuten esimerkeissä $32 a-b .^{14}$

(32) (Suomi24)

a. Eikö teitä hävetä ostaa viinaa ruokakaupasta.

b. Ja mua nolottaa mennä 6 luokalle ens vuonna.

Tuntemusverbien jäljessä A-infinitiivi esiintyy keskimäärin 2 prosentissa ja tunneverbeillä 6 prosentissa kaikista kyseisten verbien indikatiivimuotoisista esiintymistä. A-infinitiivi voi liittyä ruumiillisen tuntemuksen aiheuttamiseen kuten esimerkeissä 33a-c. Kaikki käsittelemäni tunneverbit esiintyvät Suomi24-korpusaineistossa toisinaan A-infinitiivin kanssa, mutta osa etenkin ruumiillista tuntemusta ilmaisevista verbeistä (esim. hikoiluttaa, jomottaa) on A-infinitiivin kanssa harvinaisia.

\section{(33) (Suomi24)}

a. köh köh kun yskittää pyöräillä hämeentiellä

b. viluttaa istua tässä ja odotella kahvin valmistumista

c. ni ei ihme, ettei hiuo syödä noita omppuja lidlistä

On kuitenkin yleisempää, että tuntemusverbit ilmaisevat A-infinitiivin yhteydessä ruumiillisen tuntemuksen sijaan mentaalista tilaa kuten esimerkeissä $34 \mathrm{a}-\mathrm{f}$.

12. Korpukseen kuuluvat kaikki Suomi24 -keskustelufoorumin tekstit ajalta 1.1.2001-24.9.2016. Korpus sisältää morfosyntaktisen analyysin, jonka on tuottanut Kielipankki, FIN-CLARIN. Tekstiaineistoon voi tehdä hakuja Korp-käyttöliittymän kautta (korp.csc.fi).

13. Aineistoon kuuluvat tunneverbit harmittaa, hävettää, hirvittää, ihmetyttää, inhottaa, kaduttaa, kiukuttaa, korveta, nolottaa, pänniä, risoa, säälittää, sapettaa, surettaa, tympiä, ujostuttaa, vituttaa ja ällöttää sekä tuntemusverbit aivastuttaa, heikottaa, hikoiluttaa, hiukoa, huimata, janottaa, jomottaa, kihelmöidä, kirvellä, kuumottaa, kuvottaa, närästää, oksettaa, puistattaa, pyörryttää, vihloa, viluttaa ja yskittää.

14. Tämä lähestymistapa jättää huomiotta lauseet, joissa verbin ja A-infinitiivin väliin sijoittuu muita elementtejä, kuten Minua harmittaa aina lähteä kotiin. Tällaisten tapausten merkitys päätelmien kannalta on kuitenkin vähäinen. 


\section{(34) (Suomi24)}

a. Minua vihloi nähdä sinut toisen tytön kanssa - -

b. Sielua kirvelee lukea näitä pesuaineen ja rätin kanssa tuhraajia - -

c. Jos noin närästää nähdä lihavia naisia televisiossa - -

d. Vähän heikottaa mennä äänestämään.

e. Joku vuosi takaperin kihelmöi ostaa tuollainen --

f. Varmasti palelee olla tuollaisessa suhteessa.

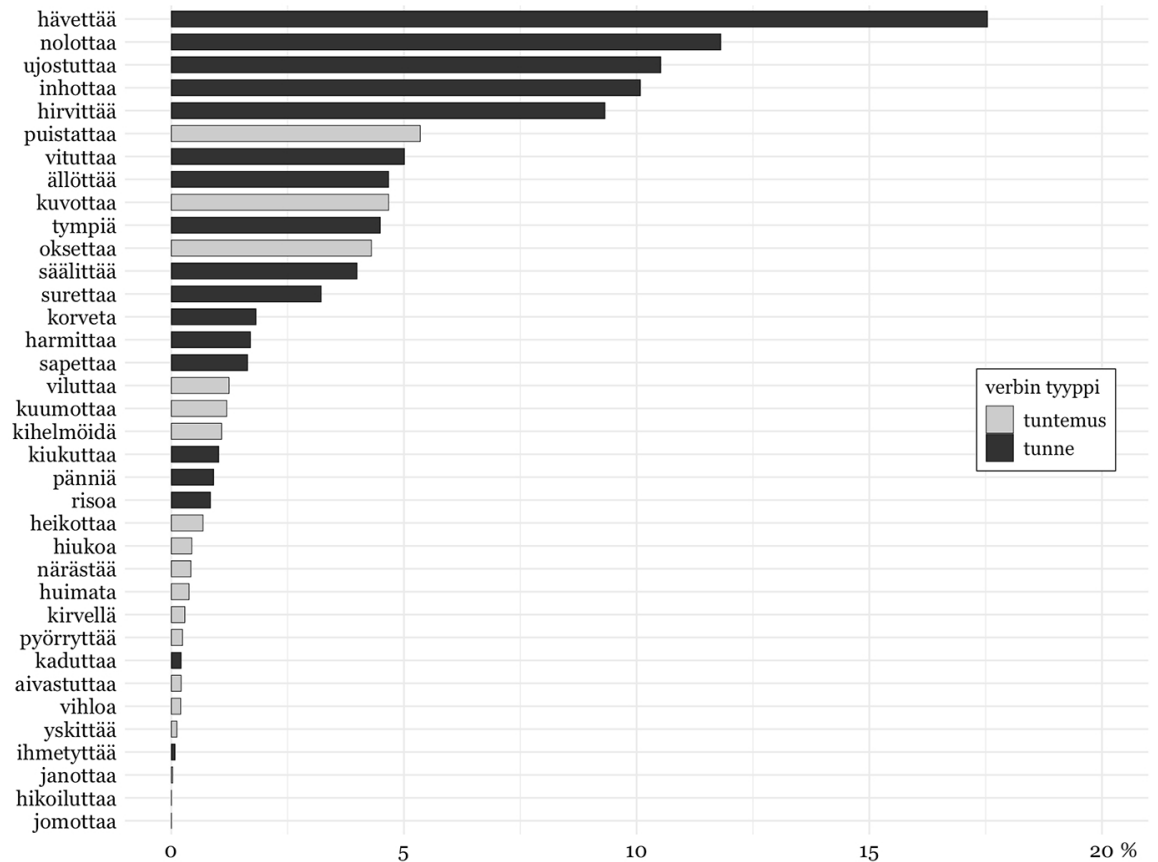

Kuvio 3.

Tunnekausatiiviverbit, joita seuraa välittömästi A-infinitiivi. Osuus kaikista kyseisen verbin indikatiivimuotoisista esiintymistä. ${ }^{15}$

\subsubsection{Kun-lause}

Välittömästi tunnekausatiiviverbin jäljessä sijaitsevien kun-lauseiden tarkastelu osoittaa, että samoin kuin A-infinitiivi, kun-lause seuraa tunnekausatiivia useammin tunneverbien kuin tuntemusverbien yhteydessä (ks. kuviota 4 seur. sivulla). Alustavan tarkastelun perusteella vaikuttaa myös siltä, että kausaalisten kun-lauseiden osuus kaikista kun-lauseista on suurempi tunneverbeillä kuin tuntemusverbeillä. Tämän tuloksen vahvistaminen jää kuitenkin jatkotutkimuksen tehtäväksi.

15. Kuviosta on jätetty pois tuntemusverbit jomottaa, hikoiluttaa, janottaa, yskittää, vihloa ja tunneverbi ihmetyttää. Näiden verbien esiintymämäärä A-infinitiivin kanssa suhteessa kaikkiin esiintymiin oli vähäinen. 


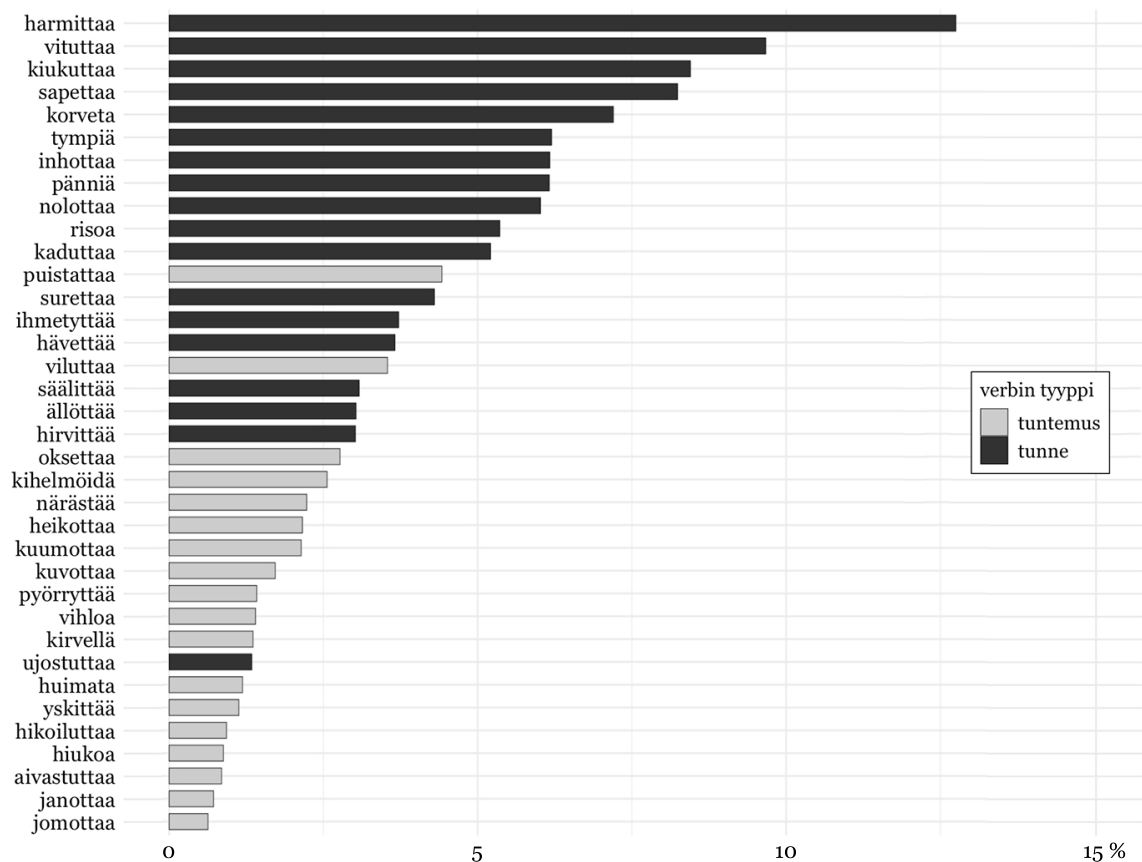

Kuvio 4.

Tunnekausatiiviverbit, joita seuraa välittömästi kun-lause. Osuus kaikista kyseisen verbin indikatiivimuotoisista esiintymistä. Kuvioon sisältyvät kaikki kun-lauseet, sekä kausaaliset että temporaaliset. ${ }^{16}$

\subsubsection{Että-lause}

Lopuksi voidaan todeta, että että-lauseen tarkastelu on linjassa A-infinitiiveistä ja kunlauseista esitettyjen havaintojen kanssa. Kuvion 5 perusteella että-lause on selvästi yleisempi tunneverbien kuin tuntemusverbien yhteydessä. Että-lausetta koskeva aineisto sisältää kuitenkin enemmän epäselviä tapauksia kuin A-infinitiivin sisältävät esiintymät. Yksittäisten tunneverbien tympiä, sapettaa ja vituttaa perusteella on mahdollista päätellä, että epäselvien tapausten osuus aineistosta on noin 20-30 \%. Kuvion 5 tulokset ovat siis vain suuntaa antavia. ${ }^{17}$

16. Kuviosta on jätetty esitysteknisistä syistä pois tunneverbit jomottaa, hiukoa, hikoiluttaa, janottaa, yskittää ja huimata, jotka esiintyvät hyvin harvoin välittömästi kun-lauseen yhteydessä.

17. Esimerkiksi verbien tympiä, sapettaa ja vituttaa yhteydessä esiintyvistä että-lauseista 85-88 \% toimii tunnekausatiivilauseessa aiheuttajana. Toisaalta tuntemusverbien, kuten ujostuttaa, kanssa esiintyessään että-lause voidaan tulkita aiheuttajaksi vain noin 28 prosentissa tapauksista. Lisäksi analyysin ulkopuolelle on jätetty monimutkaisempia että-lauseen esiintymiä, joita on listattu esimerkissä (i). NPlausekkeen sisälle sijoittuvien että-lauseiden tarkempi analyysi jää jatkotutkimuksen aiheeksi.

(i) a. Se eniten sapettaa, että - -

b. Pelkkä ajatus huvittaa että noin ajattelevia miehiä on olemassa.

c. - - nenä tukossa, yskittää että meinaa tukehtua. 


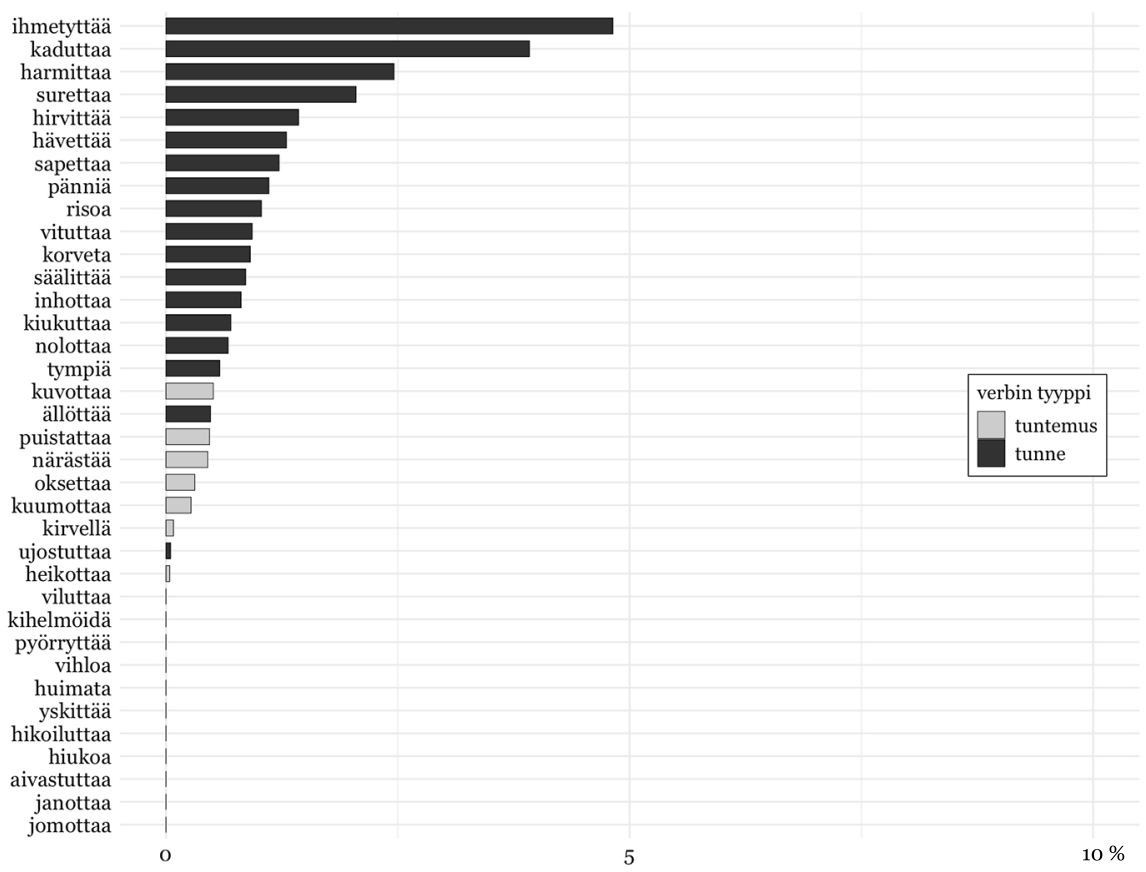

Kuvio 5.

Tunnekausatiiviverbit, joita seuraa välittömästi että-lause. Osuus kaikista kyseisen verbin indikatiivimuotoisista esiintymistä. ${ }^{18}$

Luvussa 4 esitin, että lausemaiset aiheuttajat asettuvat tyypillisesti komplementtipositioon. Tarkastellun aineiston perusteella voidaan todeta, että tunnekausatiiviverbin luokka korreloi siis sen kanssa, kuinka yleisesti verbin komplementtipositio on käytössä. Komplementtiposition yleisyys voi osaltaan selittää Pörnin (2001) havaintoa, että kun-lause tulkitaan kausatiiviseksi useammin tiettyjen tunneverbien yhteydessä kuin tuntemusverbien. Aineistosta voidaan päätellä, että lausemaiset aiheuttajat liittyvät etenkin mentaalisen tilan aiheuttamiseen, mutta verbikohtainen variaatio on suurta.

\section{Päätelmät}

Tässä artikkelissa olen tarkastellut tunnekausatiiveja, joilla on lausemainen aiheuttaja. Olen osoittanut, että A-infinitiivi sijoittuu tunnekausatiivilauseen argumenttirakenteessa komplementtipositioon samoin kuin aiheuttajana toimiva että-lause. Lisäksi olen esittänyt, että kun-lause voi esiintyä sekä adjunkti- että komplementtipositiossa.

18. Tuntemusverbien aivastuttaa, hiukoa, viluttaa, pyörryttää, vihloa ja janottaa esiintymät on jätetty pois kuviosta niiden vähäisen määrän takia. 
Lausemaisten aiheuttajien tarkastelu korpusaineiston valossa avaa uusia näkökulmia tunnekausatiivien luokitteluun. A-infinitiivi on keskimäärin yleisempi mentaalista tilaa kuvaavien tunneverbien kuin tuntemusverbien yhteydessä; ero näyttää liittyvän verbien merkityssisältöön. Tarkastelemani verkkokeskusteluaineiston perusteella osa tavallisesti ruumiilliseen tuntemukseen liitetyistä tuntemusverbeistä, kuten puistattaa, oksettaa ja kuvottaa, on käytössä myös mentaalisen tilan kuvaajina. On myös syytä huomata, että verbit näyttävät muodostavan rakenteen suhteen jatkumon selvärajaisten luokkien sijaan. Tunnekausatiivi on karttuva verbiluokka, mikä voi vaikuttaa tiettyjen rakenteiden yleistymiseen puhekielessä. Toisena selittävänä tekijänä voi olla tunnekausatiivien tapaisten subjektiivisten ilmaisujen yleisyys Internet-keskusteluaineistossa. Siiroisen (2002) mukaan tunnekausatiivi on subjektiivinen ja egosentrinen ja ilmaantunut siksi kirjoitettuun kieleen myöhään. Vaikka tunnekausatiivilauseita esiintyy myös vanhemmissa kaunokirjallisissa ja lehtiteksteissä, vasta keskusteluaineistojen tarkastelu antaa kuvan rakenteen laajuudesta ja monipuolisuudesta.

\section{Lähteet}

\section{Aineistolähteet}

Internet $1=$ https://www.suomentilintarkastajat.fi/blogi/talouden-ammattilaisille/mika-tilinpaatoksessa-kiinnostaa-tilintarkastaja-paula-roiman-vinkit (4.12.2019).

Internet $2=$ https://deskgram.co/explore/tags/turkubestplaces (4.12.2019).

Internet 3 = https://identio.fi/podcast/episode/anchor-episode-f2d2826a-e440-ec635298-0oo8c4do7ba2 (4.12.2019).

Internet 4 = https://www.rapport.fi/journalistit/elisa-helenius/dansot-ovat-pojiksi-pukeutuviajapanilaistyttoja-jotka-esittavat-unelmaseuralaisia (4.12.2019).

Suomi24 = Aller Media Oy 2014. Suomi 24 -korpus (2016H2) [tekstikorpus]. Kielipankki. http:// urn.fi/urn:nbn:fi:lb-2017021506.

\section{Kirjallisuuslähteet}

Cathcart, M.E. -Vainikka, Anne 2019: Re-analysis of causative morphology in Finnish. Käsikirjoitus, viitattu 9.8.2019. University of Delaware.

Сномкку, Noам 1981: Lectures in government and binding. The Pisa lectures. Dordrecht: Foris.

Haegeman, Liliane 1991: Introduction to government and binding theory. Oxford: Blackwell. Hakulinen, Auli - Karlsson Fred 1979: Nykysuomen lauseoppia. Helsinki: Suomalaisen Kirjallisuuden Seura.

Herlin, Ilona 1998: Suomen kun. Helsinki: Suomalaisen Kirjallisuuden Seura.

Huhmarniemi, SAARA 2012: Finnish A'-movement. Edges and islands. Institute of Behavioural Sciences, Studies in Cognitive Science 2. Helsinki: University of Helsinki. http://urn.fi/ URN:ISBN:978-952-10-7712-8. 
2019: Tunnekausatiivilauseen argumenttirakenne I. NP aiheuttajana. - Virittäjä 123 s. 373-400. https://doi.org/10.23982/vir.63416.

Koskinen, PÄIvi 1998: Features and categories. Non-finite constructions in Finnish. Toronto Working Papers in Linguistics. Toronto: University of Toronto.

Kupula, Mıко 2010: Causers as derived subjects. An unaccusative view from Finnish. - Working Papers in Scandinavian Syntax 86 s. 199-219.

Lagus, Krista - Panzar, Mika - Ruckenstein, Minna - Ylisiurua, Marjoriikka 2016. SUOMI24: Muodonantoa aineistolle. Kuluttajatutkimuskeskus, Valtiotieteellisen tiedekunnan julkaisuja 10. Helsinki: Helsingin yliopisto. https://researchportal.helsinki.fi/ fi/publications/suomi24-muodonantoa-aineistolle.

Leino, Pent ti 1986: Infinitiivin asema lauseessa. Pentti Leino \& Jyrki Kalliokoski (toim.), Kieli 1 s. 103-156. Helsingin yliopiston suomen kielen laitos.

Nelson, Diane 2000: Linking causatives and experiencers. - Leeds working papers in linguistics 8 s. $149-177$.

- 2003: Case and event structure in Finnish psych predicates. - Ellen Brandner \& Heike Zinsmeister (toim.), New perspectives on case theory s. 191-221. Stanford: CSLI Publications.

PyLKKäNEN, LIINA 2002: Introducing arguments. Cambridge, MA: MIT, Department of Linguistics and Philosophy.

Pörn, Michaela 2001: Valinnaisesti ja pakollisesti kausatiiviset tunnekausatiivit ja niiden argumenttirakenne. - Puhe ja kieli 21 s. 115-128.

Ross, John Robert 1967: Constraints on variables in syntax. Cambridge, MA: MIT, Department of Linguistics and Philosophy.

SiIroinen, MARI 2001: Kuka pelkää, ketä pelottaa. Nykysuomen tunneverbien kielioppia ja semantiikkaa. Helsinki: Suomalaisen Kirjallisuuden Seura.

— 2002: "Jopas kortittaa”. - Ilona Herlin, Jyrki Kalliokoski, Lari Kotilainen \& Tiina OnikkiRantajääskö (toim.), Äidinkielen merkitykset s. 210-227. Helsinki: Suomalaisen Kirjallisuuden Seura.

- 2005: An overview of mental verbs in Finnish. - MMJ Fernandez-Vest (toim.), Les langues ouraliennes aujourd'hui. The Uralic Languages Today s. 316-326. Paris: Champion.

Siro, PaAvo 1996 [1978]: Kausatiivien kielioppia. - Pentti Leino (toim.), Lauseopin periaatteita. Kaksitoista artikkelia s. 129-196. Helsinki: Helsingin yliopiston suomen kielen laitos.

Tolvonen, IdA 1995: A study of Finnish infinitives. Maisterintutkielma. Brandeis University.

Trosterud, Trond 1993: Anaphors and binding domains in Finnish. - Anders Holmberg \& Urpo Nikanne (toim.), Case and other functional categories in Finnish syntax s. 225-243. New York: Mouton de Gruyter.

VAINIKKa, Anne 1989: Deriving syntactic representations in Finnish. Amherst, MA: University of Massachusetts.

VILKUNA, MARIA 1989: Free word order in Finnish. Its syntax and discourse functions. Helsinki: Suomalaisen Kirjallisuuden Seura.

VisK = Hakulinen, Auli - Vilkuna, Maria - Korhonen, Rittta - Koivisto, Vesa - Heinonen, Tarja Rittta - Alho, Irja 2004: Ison suomen kielioppi. Helsinki: Suomalaisen Kirjallisuuden Seura. Verkkoversio. http://scripta.kotus.fi/visk URN:ISBN:978-952-5446-35-7 (20.2.2018). 


\section{The argument structure of the Finnish experiencer construction II: An embedded clause as a causer argument}

This paper investigates the Finnish experiencer construction, which involves a psychological predicate and two optional arguments: the nominative causer and the partitive experiencer. The causer argument can be clausal, such as the A infinitive, the kun clause, a finite clause headed by the complementizer että, or an embedded interrogative clause.

Mua jännittää kertoa tämä sulle. (colloquial)
I.PAR
'I'm excite.CAUS.PREs.3SG tell.INF this.NOM

The aim of this paper is to show within the framework of generative syntax that the A infinitive and the finite complement clause occupy the complement position in the experiencer construction, while the kun clause may occupy either the adjunct or complement position. The syntactic analysis is complemented with a corpus analysis of a corpus taken from the Suomi24 online messaging site. The comprehensive Finnish grammar divides experiencer verbs into two classes: those that express emotion and those that express sensation. The corpus analysis shows that verb type correlates with the frequency of a clausal causer.

This article is the second in a series of two. The first article investigated constructions in which the causer argument was an NP. It demonstrated that the causer NP occupies a higher position in the argument structure than the experiencer NP. In this article, the author argues that a clausal causer occupies a lower position than the experiencer. This means that the experiencer construction has alternating argument structures for different types of causers. 


\section{Tunnekausatiivilauseen argumenttirakenne II: Lausemainen aiheuttaja}

Suomen tunnekausatiivilause muodostuu tunnetta ilmaisevasta verbistä, johon liittyy tyypillisesti partitiivimuotoinen kokija, aiheuttaja tai kumpikin. Aiheuttaja voi olla paitsi nominatiivimuotoinen NP myös lausemainen, kuten A-infinitiivi, kunlause, että-lause tai alisteinen kysymyslause. Tämän artikkelin tavoitteena on osoittaa generatiivisen syntaksin työkaluja käyttäen, että A-infinitiivi ja että-lause sijoittuvat tunnekausatiivilauseen argumenttirakenteessa komplementtipositioon, kun taas aiheuttajana toimiva kun-lause voi sijoittua joko adjunkti- tai komplementtipositioon. Lisäksi artikkelissa esitetään Suomi24-korpusaineiston perusteella, että tunnekausatiivien luokittelu tunne- ja tuntemusverbeihin korreloi lausemaisen aiheuttajaargumentin yleisyyden kanssa.

Artikkeli on toinen osa kahden artikkelin sarjasta. Ensimmäisessä osassa esitettiin, että aiheuttajana toimiva NP asettuu rakenteessa tyypillisesti ylemmäs kuin kokija. Koska lausemainen aiheuttaja asettuu välttämättä komplementtiin ja alemmas kuin kokija, tunnekausatiivilauseen argumenttirakenne näyttää siis vaihtelevan ainakin aiheuttaja-argumentin tyypin mukaan.

Kirjoittajan yhteystiedot (address):

etunimi.sukunimi@helsinki.fi

Kirjoittaja on kognitiotieteen post doc -tutkija Helsingin yliopistossa. 